\title{
Pemeriksaan MPN (Most Probable Number) Coliform dan Identifikasi Escherichia Coli pada Jamu Gendong Beras Kencur
}

\section{Examination of MPN (Most Probable Number) Coliform and Identification of Escherichia Coli on Herbal Powder for Kencur Rice}

\author{
AMELLIA VALENTINA RANDI SAPUTRO
}

\author{
Jurusan Analis Kesehatan Poltekkes Kemenkes Semarang \\ Jl. Wolter Monginsidi Pedurungan Tengah Semarang \\ E-mail: liiavallentina@gmail.com
}

\begin{abstract}
Abstrak
Jamu gendong beras kencur merupakan minuman tradisional yang masih dikonsumsi oleh masyarakat. Proses pembuatan yang masih menggunakan peralatan manual dan tradisional serta kurangnya perhatian terhadap kebersihan menjadi salah satu faktor penyebab terkontaminasinya jamu dengan bakteri. Berdasarkan Peraturan Badan Pengawas Obat Dan Makanan Republik Indonesia Nomor HK.00.06.1.52.4011 Tahun 2009 tentang Penetapan Batas Maksimum Cemaran Mikroba Dan Kimia Dalam Makanan, batas maksimum pencemaran bakteri coliform yaitu $20 / \mathrm{ml}$. Tujuan penelitian ini yaitu untuk mengetahui pencemaran bakteri Coliform dan mengidentifikasi bakteri Escherichia coli pada jamu gendong beras kencur di Pasar Peterongan Semarang. Penelitian ini merupakan penelitian deskriptif dengan pendekatan cross sectional. Jumlah sampel yaitu 4 jamu gendong beras kencur yang dijual di Pasar Peterongan, dan pemeriksaan dilakukan secara duplo. Hasil pemeriksaan bakteri Coliform pada sampel jamu gendong beras kencur yaitu $100 \%$ positif mengandung bakteri Coliform, dan dari keempat sampel tersebut, $75 \%$ sampel jamu teridentifikasi bakteri Escherichia coli, sehingga dapat disimpulkan bahwa sampel jamu gendong beras kencur yang dijual di Pasar Peterongan Semarang tercemar oleh bakteri Coliform dan Escherichia coli.
\end{abstract}

Kata Kunci: Jamu ; Coliform ; MPN

\begin{abstract}
Herbal medicine of kencur rice is a traditional drink that is still consumed by the community. The manufacturing process is still using manual and traditional equipment and the lack of attention to cleanliness has become one of the factors causing contamination of herbs with bacteria. Based on the Regulation of the Food and Drug Supervisory Agency of the Republic of Indonesia Number. HK.00.06.1.52.4011 of 2009 on Determination of Maximum Limit of Microbial and Chemical In Food Contamination, maximum limit of coliform bacteria contamination on herbal medicine is $20 \mathrm{MPN} / \mathrm{ml}$. The purpose of research is to know the contamination of Coliform bacteria and to identify Escherichia coli in herbs medicine kencur at Peterongan Market. Method of the research is a descriptive research with cross sectional approach. The number of samples are 4 herbs of kencur packet sold in Peterongan Market, and the inspection is done in duplo. The result of Coliform bacteria examination on the samples of herbal medicine of kencur 100\% containing Coliform bacteria, and of the four samples, $75 \%$ samples were identified Escherichia coli, so herbs samples of kencur sold in the market Peterongan Semarang, contaminated by Coliform bacteria and Escherichia coli.
\end{abstract}

Keyword: Herbs ; Coliform ; MPN 


\section{Pendahuluan}

Undang - Undang Kesehatan Republik Indonesia Nomor 36 Tahun 2009 tentang Kesehatan, kesehatan adalah keadaan sehat, baik secara fisik, mental, spiritual, maupun sosial yang memungkinkan setiap orang untuk hidup produktif secara sosial dan ekonomi. Salah satu bahan yang menunjang kesehatan yaitu obat. Obat adalah bahan tunggal atau campuran yang digunakan oleh semua mahluk untuk bagian dalam maupun luar, guna mencegah, meringankan, maupun menyembuhkan. Obat terbagi menjadi dua yaitu obat kimia dan obat tradisional (Syamsuni, 2006).

Jamu adalah obat tradisional yang digunakan secara turun temurun berdasarkan pengalaman menggunakan bahan yang belum terstandar (Kepmenkes RI No.261/Menkes/SK/IV/2009). Jamu merupakan salah satu obat tradisional yang sangat diminati masyarakat karena harganya terjangkau dan mudah diperoleh, terutama dari penjual jamu gendong yang banyak dijumpai, baik di kota maupun di desa. Usaha jamu gendong terus berkembang sesuai dengan kebutuhan masyarakat yang banyak menggunakannya sebagai minuman penyegar atau obat penyakit ringan. (Suharmiati, 2003).

Pembuatan jamu gendong secara umum dibedakan menjadi dua macam, yakni dengan cara merebus seluruh bahan atau mengambil (memeras sari) yang terkandung di dalam bahan baku, kemudian mencampurnya dengan air matang. Beberapa bahan ramuan yang akan direbus dan diperas, biasanya diiris-iris atau dihancurkan terlebih dulu. (Suharmiati, 2003).

Pada umumnya jamu gendong dibagi menjadi beberapa jenis jamu, salah satunya yaitu jamu gendong beras kencur. Jamu gendong beras kencur merupakan jamu yang paling sering dikonsumsi oleh anak-anak, remaja maupun dewasa dan dapat ditemukan di pasar-pasar tradisional. Bahan utama jamu gendong beras kencur yaitu kencur (Kaempferia galanga).

Jamu gendong beras kencur dijual di pasar-pasar tradisional. Salah satunya yaitu pasar Peterongan Semarang. Berdasarkan observasi yang telah dilakukan oleh peneliti, Pasar Peterongan memiliki hygiene sanitasi yang masih kurang baik. Hal ini dibuktikan dengan kondisi lingkungan yang banyak terdapat lalat, air yang menggenang, dan persediaan air bersih yang masih belum memadahi. Pada beberapa penjual jamu gendong beras kencur di pasar Peterongan Semarang, jamu ditempatkan menggunakan botol plastik yang kurang bersih dan sedikit menghitam. Air yang digunakan untuk mencuci gelas yang telah digunakan pun terlihat keruh. Hal tersebut dapat menjadi sumber pencemaran bakteri coliform dan dapat menyebabkan penyakit diare.

Pada proses pembuatan jamu dalam jumlah yang besar juga akan memberikan peluang terjadinya pencemaran yang lebih tinggi. Salah satu faktor yang mempengaruhi pencemaran pada jamu gendong beras kencur adalah kurangnya perhatian pada kebersihan, baik kebersihan bahan baku, peralatan yang digunakan, kebersihan lingkungan serta kebersihan pembuat jamu (Suharmiati, 2003).

Berdasarkan penelitian yang dilakukan oleh Fahmadila Jilan Maulida, Khoiron, Prehatin Tri R.N, menunjukkan bahwa hygiene sanitasi mempengaruhi pencemaran bakteri pada jamu. Hal ini dibuktikan dari 45 sampel jamu gendong, 18 diantaranya mengandung bakteri Escherichia coli.

Salah satu cara mencegah pencemaran bakteri tersebut yaitu menjaga kebersihan dan kualitas makanan maupun minuman yang akan dikonsumsi. Pemeriksaan yang digunakan untuk mengetahui jumlah total bakteri coliform pada minuman, dapat dilakukan dengan menggunakan metode MPN (Most Probable Number). Berdasarkan Peraturan Badan Pengawas Obat Dan Makanan Republik Indonesia Nomor. HK.00.06.1.52.4011 Tahun 2009 tentang Penetapan Batas Maksimum Cemaran Mikroba Dan Kimia Dalam Makanan, batas maksimum pencemaran bakteri coliform pada minuman (sari buah dan sayuran) yaitu 20 $\mathrm{MPN} / \mathrm{ml}$. 


\section{Metode}

Jenis penelitian yaitu penelitian deskriptif dengan pendekatan cross sectional. Hasil penelitian yang didapat, kemudian disajikan dalam bentuk tabel dan diagram dan dideskripsikan. Metode penelitian yang digunakan yaitu Most Probable Number (MPN), untuk menghitung jumlah bakteri terdekat yang ada pada sampel. Alat yang digunakan yaitu tabung reaksi, tabung durham, ose, cawan petri, bunsen, autoclave, BSC, pipet volume, kapas dan beaker glass. Bahan yang digunakan yaitu sampel jamu, media Endo Agar, media Lactosa Broth, media BGLB, media IMVIC, NaCl Fisiologis, reagen covac's, Methyl Red, $\alpha$-Naphtol dan $\mathrm{KOH} 40 \%$.

\section{Hasil dan Pembahasan}

Pada penelitian ini jumlah sampel jamu gendong beras kencur yang digunakan yaitu sebanyak 4 sampel yang dijual di Pasar Peterongan Semarang, dan dilakukan dua kali pemeriksaan pada setiap sampel. Sampel jamu gendong beras kencur diambil sebanyak \pm 250 $\mathrm{ml}$ tiap sampel. Pengambilan sampel dilakukan pada hari Kamis 25 Januari 2018, pukul 07.00 WIB. Wadah sampel yang digunakan yaitu botolkaca steril, kemudian sampel jamu dibawa ke laboratorium menggunakan cool box.

Tabel 1. Hasil Pemeriksaan Bakteri Coliform pada Jamu Gendong Beras Kencur yang dijual di Pasar Peterongan Semarang.

\begin{tabular}{cccc}
\hline $\begin{array}{c}\text { Kode } \\
\text { Sampel }\end{array}$ & $\begin{array}{c}\text { Hasil Tes } \\
\text { Lengkap }\end{array}$ & $\begin{array}{c}\text { Jumlah Bakteri Coliform } \\
(\mathrm{MPN} / \mathrm{ml})\end{array}$ & $\begin{array}{c}\text { Standar BPOM } \\
(\mathrm{MPN} / \mathrm{ml})\end{array}$ \\
\hline Sampel A & + & $>2400$ & 20 \\
\hline Sampel B & - & 58 & 20 \\
\hline Sampel C & + & $>2400$ & 20 \\
\hline Sampel D & + & $>2400$ & 20 \\
\hline
\end{tabular}

Keterangan Tabel :

- = Negatif Escherichia coli

$+=$ Positif Escherichia coli

Berdasarkan tabel tersebut dapat diketahui bahwa keempat sampel jamu yang digunakan, positif mengandung bakteri Coliform, dengan jumlah $>2400 \mathrm{MPN} / \mathrm{ml}$ pada sampel A, C, dan $\mathrm{D}$, serta pada sampel B berjumlah $58 \mathrm{MPN} / \mathrm{ml}$. Keempat sampel tersebut positif mengandung bakteri Coliform yang dibuktikan dengan didapatnya hasil positif pada media LB dan media BGLB.

Tiga dari empat sampel jamu teridentifikasi bakteri Escherichia coli, yaitu pada sampel jamu A, C dan D. Hal ini dibuktikan dari tes lengkap yang berupa tumbuhnya koloni bakteri Escherichia coli pada media Endo Agar berwarna merah metalik. Kemudian dilakukan uji lanjutan berupa uji IMVIC, dimana hasil uji IMVIC pada bakteri Escherichia coli yaitu Indole positif, $M R$ positif, $V P$ negatif dan $S C$ negatif ( + + - ). Pada sampel B koloni yang tumbuh pada media Endo Agar berwarna merah muda, bukan merah metalik (yang dicurigai sebagai bakteri Escherichia coli), sehingga tidak dilanjutkan dengan uji IMVIC.

Hasil pemeriksaan laboratorium mengenai Most Probable Number (MPN) bakteri coliform dan identifikasi bakteri Escherichia coli terhadap empat sampel jamu gendong beras kencur yang dijual di Pasar Peterongan Semarang, didapatkan hasil keempat sampel jamu gendong beras kencur tersebut mengandung bakteri coliform, dan tiga diantaranya teridentifikasi bakteri Escherichia coli, yait u sampel jamu A, C dan D.

Menurut Peraturan Kepala Badan Pengawas Obat dan Makanan Republik Indonesia Nomor HK.00.06.1.52.4011 Tahun 2009 Tentang Penetapan Batas Maksimum Cemaran 
Mikroba dan Kimia dalam Makanan, batas maksimum cemaran bakteri coliform pada minuman (sari buah dan sari sayuran) yaitu $20 \mathrm{MPN} / \mathrm{ml}$.

Pada proses persiapan pembuatan jamu gendong beras kencur memiliki peluang yang besar terhadap pencemaran bakteri. Salah satunya yaitu kurangnya perhatian terhadap kebersihan, baik kebersihan alat dan bahan yang akan digunakan, maupun personal hygiene penjual jamu (Suharmiati, 2003). Peralatan dan bahan baku yang akan digunakan harus dicuci bersih menggunakan air mengalir, agar kotoran yang menjadi sumber bakteri dapat ikut terbawa oleh air. Berdasarkan kuisioner yang telah diisi oleh penjual jamu, keempat penjual jamu gendong beras kencur di Pasar Peterongan tidak mencuci tangan dengan baik dan benar sebelum membuat jamu. Keempat penjual jamu tersebut mencuci tangan pada air yang menggenang. Hal tersebut juga dapat menjadi salah satu sumber cemaran bakteri. Bakteri yang menempel pada tangan akan menempel pada peralatan dan tercampur dengan jamu tersebut.

Salah satu faktor yang dapat menyebabkan adanya bakteri coliform dan Escherichia coli, yaitu sumber air yang digunakan. Air sumur menjadi salah satu faktor penyebab adanya kontaminasi bakteri coliform pada air, terutama coliform fecal yaitu bakteri Escherichia coli. Sumur atau wilayah yang dekat dengan septic tank, merupakan penghasil bakteri coliform fecal yang lebih tinggi (Eukene, 2014). Berdasarkan SNI 03-2916-1992, jarak sumur gali untuk sumber air bersih dengan sumber pengotoran (septic tank / bidang resapan) yaitu lebih dari 11 meter.

Berdasarkan hasil pemeriksaan laboratorium pada sampel jamu gendong beras kencur, didapatkan hasil tiga sampel tercemar bakteri Escherichia coli, yaitu sampel jamu A, C dan D. Pada sampel A dan C, sumber air yang digunakan yaitu air PDAM, sedangkan pada sampel D sumber air yang digunakan yaitu air sumur. Air sumur memiliki resiko yang cukup tinggi sebagai sumber dari pencemaran bakteri Escherichia coli. Sedangkan air PDAM memiliki resiko yang rendah sebagai sumber dari pencemaran bakteri Escherichia coli, karena air PDAM telah melalui beberapa tahap pengolahan serta mengandung desinfektan berupa chlorin yang digunakan untuk membunuh bakteri. Air PDAM juga dilakukan pemeriksaan laboratorium kualitas air secara periodik.

Kontaminasi bakteri coliform maupun Escherichia coli dari sumber air yang digunakan dapat dicegah dengan cara merebus air terlebih dahulu sebelum digunakan. Hal ini dapat menyebabkan bakteri coliform di dalam air mati (Annisa, 2016). Berdasarkan penelitian yang telah dilakukan oleh Saimah, Mirnawati dan Hardi Latif, disebutkan bahwa bakteri coliform (khususnya bakteri Escherichia coli) dapat mati setelah dilakukan pemanasan pada suhu $70^{\circ} \mathrm{C}$ selama 3,5 detik, dengan hasil pemeriksaan sebelum dilakukan pemanasan didapatkan jumlah bakteri sekitar $10^{5} \mathrm{CFU} / \mathrm{g}$, sedangkan hasil pemeriksaan setelah dilakukan pemanasan didapatkan jumlah bakteri $0 \mathrm{CFU} / \mathrm{g}$.

Faktor penyebab lainnya yaitu kebersihan bahan yang digunakan untuk membuat jamu. Kencur yang ditanam di tanah dekat dengan resapan atau septic tank, maupun yang dipupuk menggunakan pupuk kompos maupun pupuk kandang (berasal dari kotoran hewan), menjadi salah satu faktor pencemaran bakteri Escherichia coli pada sampel jamu. Bakteri Escherichia coli dapat tumbuh di tanah yang tercemar kotoran manusia maupun hewan.

Kebersihan gelas yang digunakan juga menjadi penyebab terjadinya kontaminasi pada sampel jamu gendong beras kencur. Berdasarkan hasil kuisioner dari penjual jamu beras kencur di Pasar Peterongan, didapatkan hasil bahwa keempat penjual jamu tersebut tidak membawa persediaan air bersih untuk mengganti air yang telah keruh/kotor karena digunakan untuk berulang kali mencuci gelas. Air yang telah keruh tersebut tetap digunakan untuk mencuci gelas hingga jamu-jamu tersebut habis terjual. Tujuan dari mencuci gelas yang telah digunakan yaitu untuk membersihkan kotoran-kotoran yang menempel pada gelas. Namun hal tersebut tidak diimbangi dengan persediaan air bersih yang cukup oleh penjual jamu. Penggunaan air yang keruh dan kotor dapat menjadi salah satu sumber pencemaran bakteri.

Berdasarkan pengamatan peneliti, pada umumnya penjual jamu gendong di Pasar Peterongan tersebut menggunakan peralatan atau wadah jamu yang sudah berulang kali 
digunakan dan tidak dicuci dengan bersih. Hal ini dibuktikan dengan kondisi wadah jamu yang sedikit menghitam dan berkerak. Kurangnya pengetahuan penjual jamu akan pentingnya kebersihan, juga menjadi salah satu faktor terjadinya kontaminasi bakteri coliform dan Escherichia coli pada jamu.

\section{Simpulan dan Saran}

\section{Simpulan}

Siswa Berdasarkan penelitian yang telah dilakukan, dapat disimpulkan bahwa $100 \%$ sampel jamu gendong beras kencur tercemar bakteri coliform dan $75 \%$ teridentifikasi bakteri Escherichia coli. Jumlah bakteri Coliform pada jamu gendong beras kencur yang dijual di Pasar Peterongan Semarang yaitu, sampel A >2400 MPN/ml, sampel B 58 MPN/ml, sampel $\mathrm{C}>2400 \mathrm{MPN} / \mathrm{ml}$ dan sampel D $>2400 \mathrm{MPN} / \mathrm{ml}$.

Berdasarkan Peraturan Kepala Badan Pengawas Obat dan Makanan Republik Indonesia Nomor HK.00.06.1.52.4011 Tahun 2009 Tentang Penetapan Batas Maksimum Cemaran Mikroba dan Kimia dalam Makanan, batas cemaran maksimum bakteri Coliform pada minuman (sari buah dan sari sayuran) yaitu $20 \mathrm{MPN} / \mathrm{ml}$.

Perlu dilakukan penelitian lanjutan mengenai pengaruh penggunaan air bersih dalam pencucian gelas yang telah digunakan, terhadap cemaran bakteri coliform pada jamu.

\section{Saran}

Disarankan bagi pemerintah daerah maupun yang berwenang memberikan pembinaan terhadap UKM jamu gendong, agar lebih memperhatikan proses pembuatan jamu gendong beras kencur yang berkualitas dan bebas dari pencemaran bakteri maupun zat lainnya.

\section{Daftar Pustaka}

BPOM RI. 2009. Peraturan Kepala Badan Pengawas Obat dan Makanan Nomor HK.00.06.1.52.4011 Tentang Penetapan Batas Maksimum Cemaran Mikroba Dan Kimia Dalam Makanan. Jakarta.

Eukene, O., Flores, M.J.L. \& Maglangit, F.F. 2014. Water Quality Asessment of Bulacao River, Cebu, Philipphines Using Fecal and Total Coliform as Indicator. Journal of Biodiversity and Environmental Science (JBES), 5(1), 470-475.

Maulida, F.J., Khoiron, Ningrum, P.T.R. 2015. Keberadaan Bakteri Escherichia coli Pada Jamu Gendong Di Jalan Sumatera Kecamatan Sumbersari Kabupaten Jember. Jember: Fakultas Kesehatan Masyarakat Universitas Jember.

Suharmiati. 2003. Menguak Tabir dan Potensi Jamu Gendong. Jakarta: Agrimedia Pustaka.

Syamsuni, H.A. 2006. Ilmu resep. Buku kedokteran. Jakarta.

Undang - Undang Republik Indonesia. 2009 Surat Keputusan Menteri Kesehatan tentang Kesehatan. Jakarta. 